British JOURNAL OF EDUCATIONAL STUdiES, ISSN 0007-1005

Vol. 48, No. 4, DeCEMber 2000, pP 371-390

\title{
VIRTUE, VICE AND VACANCY IN EDUCATIONAL POLICY AND PRACTICE
}

\author{
by Pádraig Hogan, National University of Ireland, Maynooth
}

\begin{abstract}
The incessancy of the educational reforms of recent decades in Western countries, and their prominent association with conceptions of quality drawn from industry and commerce, tend to becloud the lack of educational substance at the heart of many of the more influential of the reform patterns. This lack betokens something of a sophisticated renaissance of the late nineteenth-century mentality of payment-by-results. Exploration of the reforms also reveals a preoccupation with performance which bypasses the central concerns of education itself. Quality, in short, becomes redefined by a privative rationality, which then furnishes the conceptual arena and the predominant language for decision-making in matters educational.

Writings of two influential contemporary thinkers - MacIntyre and Lyotard - are reviewed to illustrate the nature and significance of what the reforms have neglected. These thinkers' contrasting analyses reveal how intricate the contexts of educational policy and practice have become in the pluralist circumstances of late modernity. Where MacIntyre adopts a largely traditionalist stance and Lyotard a largely dismissive one in the face of the competing inheritances which battle for the minds and hearts of learners, this paper suggests not a middle way, but a different way. This pursues a kind of thinking which is itself educational more than political, self-critical more than adversarial. Declining the path of self-assured advocacy it concentrates instead on opening up an educational issue which is more often overlooked, or busily bypassed, than understood: What actually befalls the experience of teachers and learners in the practical conduct of education? How can that experience benefit best as teaching and learning are defensibly practised? A range of communicative rather than combative virtues is identified in this connection and their promising import is briefly explored.
\end{abstract}

Keywords: indexed performance, educated public, inheritances of learning, virtues of teaching, virtues of learning 


\section{Something New, Something Old, Something Missing}

Until recent decades it has been customary to think of educational reform as something undertaken largely in response to recurring demands by teachers for more resources, for better student-teacher ratios, for new curricula to meet a greater diversity of need among pupils, for more inclusive policies in relation to disadvantaged pupils or to pupils with disabilities. Reform of this kind has usually proceeded from calls for equality and justice in schooling. It has characteristically involved additional rather than less expenditure from the public purse and has more often than not been associated with the left of the political spectrum. In recent years, however, this kind of reform, which governments were often slow to pursue, has largely been displaced by reform of another and more aggressively pursued kind.

With few exceptions, ${ }^{1}$ what is striking about the newer reforms is the inviting simplicity of the kind of analysis on which they proceed. The main features of this analysis have by now become almost commonplace and can be roughly summarised as follows. Reform is necessary chiefly because of the under-performance of schools, though to some extent also because of developmental needs of schooling in a changing society. Under-performance is essentially a matter of someone's or some party's blameworthiness within schools themselves. The chief remedy lies in restricting the discretion previously enjoyed by such persons or parties and in making them strictly accountable for outcomes that can readily be measured and compared to those achieved by other schools in an open competition for grades, pupils and resources.

Analysis of this kind is more attractive to commonsense expectations of prompt intelligibility than are analyses which explain the problems of schools, including under-achievement, by reference to a host of sociological and psychological factors. But its attractiveness has also much to do with the fact that it tends to drop from the picture the problematic contextual features of the daily work of schools and colleges, or else to relegate these features to the margins of consideration. Bearing this last point in mind, many of the international educational reform efforts of the late twentieth century can now be seen to be far from new. The thinking which informs key aspects of them reveals remarkable similarities to the payment-by-results mentality which was embraced by the British government and its colonial administrations just a century ago (Coolahan, 1977).

The straight-talking simplicity of the new reforms commends 
itself as a virtue - or more precisely a civic virtuousness - associated with clarity in the aims of schooling, transparency in its conduct, and comparability in the assessment of its outcomes. The simplicity here looks refreshing, even admirable from the standpoint of democratic accountability. Far from making the complex work of education more comprehensible however, this simplicity advances an attenuated view, indeed a simplistic one, about the very purposes of education itself. It renders these purposes swiftly vulnerable to a range of interests which are not educational in any primary sense. Where the heart of educational effort becomes a preoccupation with performance - with its testing and its indexing - it becomes very difficult to concentrate and to sustain the energies of teachers, pupils and parents on purposes of a qualitative kind: for instance those which understand education primarily as an attempt to bring about a nourishing engagement between the emergent identities of learners and the cultural inheritances which seek to address these identities. A decisive shift in long-standing priorities occurs where performance, measured by quantitative indicators, comes to occupy the centre stage; where such indicators become the chief criteria for the allocation of resources for educational efforts themselves; where the terminology of commercial life becomes the vernacular of educational decision-making; where even moral and religious education become recast as inherent features of the performance model; where democratically elected governments proclaim that this is how things should be and how things will continue to be in future.

But something further is also astir here. Rather than a mere realignment of priorities to utilitarianism in a new key, the shift just referred to betokens something more anxious; namely, a deficiency of vision and leadership. The assuring air of industriousness displayed by drives to maximise performance masks a failure to articulate or affirm substantive educational purposes, as distinct, that is, from political, economic or other purposes. But this would be to see more vice than virtue in the general thrust of educational reforms in Western democracies in the last two decades, the chief vice being that of denying to education an integrity of its own and of treating it mainly as a subsidiary and manipulable part of the machinery of modern government. More particularly, it would amount to the charge that the successive reforms that have thronged the arena of public education since the 1980s have also left it vacant of the more enduring concerns of education itself.

To argue thus is to suggest something like an aggressive benightedness among educational policymakers, coupled, at best, with an unvoiced dismay that a pressing disparity of outlooks among the 
citizenry would defeat any new efforts to promote public commitment to substantive as distinct from instrumental educational goals. Such a grim conclusion receives little encouragement or acknowledgement from Western governments themselves, who are frequently quick to pass over in silence that about which they would prefer not to speak. Conclusions just such as this feature prominently however, though in different ways, in the analyses of some of the more incisive, and socially concerned, of contemporary Western philosophers. Those include anti-modern critics like Alasdair MacIntyre on the one hand and post-modern ones like Jean François Lyotard on the other. To the extent that the major issues made explicit by such thinkers are not squarely addressed by the decision-making discourse of educational policy, educational reform continues to evade the heart of the matter. This is not to deny that its index-linked devices of assessment may well further the performances and the interests of those whom Plato once called 'the stronger party' (Republic 338c). Where the inherent purposes of education are concerned however, a preoccupation with indexing promotes a mentality of technicity and advances more than anything else an ethos of competitive individualism within schools. This bodes ill for a public undertaking purportedly dedicated not to the interests of the already strong, but to the enlightenment of each, the inclusion of the 'weaker party' and the enablement of all.

The contrasting accounts of MacIntyre and Lyotard provide an opportune way to open up the central educational issues which most of the recent educational reform movements have overlooked or forgotten. Such opening up might then enable deliberations on educational reform to pursue possibilities more pertinent and practices more promising.

\section{After Virtue, the Rise of Performativity}

In his influential book, After Virtue (1981, 1985), MacIntyre argues that the ultimate consequences of the Enlightenment and of its pluralistic legacy to Western civilisation have been chiefly baleful: the undermining of moral traditions of ancient ancestry and the promotion of a general amnesia among the public about what should properly be seen not as an enlightenment, but as a moral catastrophe of historic proportions. Announcing this as the 'disquieting suggestion' of his opening chapter MacIntyre concludes:

What we possess, if this view is true, are fragments of a conceptual scheme, parts of which now lack those contexts from which their 
significance derived. We possess indeed simulacra of morality, we continue to use many of the key expressions. But we have - very largely, if not entirely - lost our comprehension, both theoretical and practical, of morality. (1981/85, p. 2)

The bulk of After Virtue is devoted to a robust defence of this 'disquieting suggestion'. With the Enlightenment and its legacy, argues MacIntyre, 'the integral substance of morality has been fragmented and then in part destroyed.' (p. 5). He claims that the very nature of the malaise he is attempting to elucidate is one 'which almost nobody recognizes and which perhaps nobody at all can recognize fully.' (p. 4). For although he allows that the language of morality is used assertively and confidently by modern radicals and conservatives alike, MacIntyre maintains that the heterogeneity of moral sources drawn on in contemporary debates embodies ever more incommensurable conceptual premises. He insists moreover that such premises have been largely deprived of the richly textured contexts in which they were originally at home and from which they drew their coherence and authority. He concludes that this 'unharmonious melange of ill-assorted fragments' remains unrecognised for what it is because of a 'surface rhetoric of our culture' which deludes itself in its desire to 'speak complacently of moral pluralism' (p. 10). In short, on MacIntyre's analysis, to speak seriously of virtues is to speak of convictions and practices which betoken from the start a certain deference to one or more moral traditions. It is also, as a corollary, to question the capacity of reason to choose autonomously between values. The phrase 'after virtue' is used by MacIntyre to describe an age which he believes to be in thrall to the lure of such autonomy, but heedless of its rootlessness and its fragmentary consequences.

The educational implications of MacIntyre's controversial claims are pursued in his writings published subsequent to After Virtue, most notably in his books Whose Justice? Which Rationality? (1988) and Three Rival Versions of Moral Enquiry (1990), and in his address 'The Idea of an Educated Public' (published in G. Haydon, ed., Education and Values, 1987). In this last-mentioned address MacIntyre voices his belief that teachers are 'the forlorn hope of the culture of Western modernity'; that theirs is a twofold task which is now 'both essential and impossible' (1987, p. 16). This twofold task he sees as 'to fit the young person for some particular role and occupation in the social system and to enable him or herself to think for him or herself' (p. 17). MacIntyre is not saying that these two purposes would be impossible in all conceivable societies. What frustrates them, he claims, is the fact that they have been made incompatible 
with each other by cultural fragmentation and increasingly radical disparities in Western modernity.

'What modernity excludes', MacIntyre insists, 'is the possibility of an educated public' which would make the harmonious co-existence of the two main aims he has identified possible (p. 17). An educated public, he continues, requires three conditions. The first of these is the existence of a large body of people who are accomplished in the art of rational debate and whose sense of judgement might be appealed to in major matters of public concern. This body of people must understand themselves not as specialists of any kind, but as people in different walks of life who are capable of deliberating in an informed way on the more important aspects of a society's shared existence. The second condition, related to the first, is a requirement for shared acknowledgement of standards of appeal and shared assent to what would count as authoritative justification. Without such a requirement, explains MacIntyre, debate is likely to be endless and fruitless, inviting the twin dangers of scepticism on the one hand and dogmatism on the other. The first and second conditions presuppose a third, and this is described by MacIntyre as 'some large degree of shared background beliefs and attitudes, informed by the widespread reading of a common body of texts' (pp. 18-19). What MacIntyre has in mind here, as his larger writings make clear, is not merely a curriculum which grants canonical status to certain texts. He is suggesting that how these canonical texts are taught and studied is equally important. The heart of his case is that no texts can be read from a neutral standpoint; that every reading proceeds from within a tradition rather than from anything like the Enlightenment's ideal of an autonomous, or unbiased reason (1990, pp. 227-230).

The thrust of this kind of argument is that an educational goal, like independence of mind, will promote an assertive and fruitless contentiousness unless it acquiesces in some authoritative public standards of rationality; standards informed by canonical reference points which establish a certain uniformity and which thus bring diversity within coherent and manageable bounds. The premodern leanings of MacIntyre's arguments on an educated public are located firstly in his description of the intellectual and religious background of the 'Scottish Enlightenment' of the first half of the eighteenth century. But his larger writings show that these leanings reach crucially to traditions leading through European Christendom back to Greek antiquity. Such leanings carry strong implications that the 'shared background beliefs' and 'standards of appeal' of an educated public should be inspired chiefly by 
classical-Christian cultural ideals. Variants of this view have also been proposed by mid-twentieth century defenders of liberal education such as Henri Marrou (A History of Education in Antiquity, 1956) and Jacques Maritain (Education at the Crossroads, 1943, 1960). The invocation of such historically venerable traditions just a half century later however frequently provokes intense controversy, especially when the question is asked where, for instance, the aspirations of feminists, of non-white peoples, or of a range of ethnic and other minorities fit in this scheme of things. MacIntyre's vigorous reply is that the claim to truth of his own Aristotelian-Augustinian-Thomistic standpoint 'has been confirmed in its encounters with other traditions'; and that adherents of opposed standpoints could find that their efforts to establish the superior merits of such standpoints might turn out to be 'a more demanding task than has sometimes been supposed' (MacIntyre, 1988, pp. 402-403).

The traditionalist tenor of MacIntyre's views on an educated public may be vexing to many. But whether one agrees with him or not the substance of his arguments - concerning public debates about the qualitative merits of contrasting moral and cultural inheritances - cannot easily be dismissed. Insofar as the issues he tackles fit ill with the designs of reforming policymakers, this betokens how ill such designs befit the enduring purposes of what is primarily educational in character. Central to such purposes is the effort to justify particular undertakings of learning and their accomplishments among other, possibly rival ones. No less central are the standards of fluency and proficiency which distinguish both an undertaking itself and its justification. In other words, as MacIntyre's later writings show, 'excellence' concepts - like proficiency and fluency - are inseparable from the qualitative goods embodied in different forms of learning, or more precisely, embodied in students' encounters with different inheritances of learning, (1988, p. 35 ff; p. 399 ff.). Such 'excellence' concepts, MacIntyre convincingly points out, receive their full intelligibility from the realisation of those qualitative goods, most notably when such goods have to be made explicit in debates about their justification, and about their claims upon the commitments and actions of teachers and learners.

What is notable about most of the educational reforms springing from the late twentieth century, by contrast, is an avowed concern with 'quality' which largely sets aside the heart of education as a qualitative undertaking. The international preoccupation with 'performance' and 'competencies' severs concepts like proficiency and fluency from their qualitative contexts and from the substantive question of how quality in education is to be understood, justified 
and appraised. This severance is achieved mainly by recasting quality as quantity; or more precisely, by equating it with indexed performance and its quantitative measurement. What is to count as a virtue or a vice in the world of learning is also transformed in this event. In an era 'after virtue', to use MacIntyre's phrase, something of a different kind achieves the supremacy which was historically enjoyed in Western civilisations by institutionalised religion, or the supremacy sought by champions of autonomous reason under the inspirations of Enlightenment and modernity. This 'something of a different kind' turns out to be nothing other than indexed performance itself, and the palpable prowess associated with its acknowledgement.

On this point, if in little else, anti-modern arguments like those of MacIntyre find a strong echo in the post-modern arguments of writers like Jean François Lyotard. In his book The Postmodern Condition: A Report on Knowledge (1979 French, 1984 English) Lyotard introduces his arguments by offering summary descriptions of the condition of knowledge and learning in the most highly developed societies'. He holds that grand ideals widely influential in the past ('metanarratives') - including those of the emancipation of reason associated with the era of modernity - have lost their power to inspire, to justify, to 'legitimate'. He suggests that the most highly developed societies can now be described as 'postmodern' rather than modern. Simplifying his opening argument to its essentials he writes, 'I define postmodern as incredulity towards metanarratives' (pp. xxiii-xxiv). Pursuing the educational implications of this argument, Lyotard maintains that liberal or emancipatory ideals of learning have practically been superseded by functional ones:

$[\mathrm{T}]$ he transmission of knowledge is no longer designed to train an elite capable of guiding the nation towards its emancipation, but to supply the system with players capable of acceptably fulfilling their roles at the pragmatic posts required by its institutions. (1979, p. 48).

He claims that in such a context, described as 'a vast market for competence in operational skills' (p. 51), 'performativity' becomes a value par excellence and a concern with justification and rights gets set aside. Or as his own analysis puts it, " $[R]$ ights do not flow from hardship, but from the fact that the alleviation of hardship improves the system's performance' (p. 63). Lyotard perceives in the postmodern context he is describing an evasion of substantive issues which is achieved by assimilating work, politics and education to the requirements of a system and its maximum performance. The 
system marks a triumph of technocratic reason. It acts as a 'vanguard machine' which drags humanity after it, 'dehumanising it in order to rehumanise it at a different level of normative capacity' (p. 63). The 'ideology of the system' fills with its own substitutes the moral space formerly occupied by debates over ideals of emancipation and justice. The new substitutes are effectiveness and efficiency, success and power. Their relation to moral accomplishments (crucial, for instance, in the philosophy of Aristotle) has been severed - irrevocably so, to Lyotard's mind.

To make a comparison at this point, in both After Virtue and The Postmodern Condition attention is drawn to the demise of moral traditions of long ancestry and influence, and to the consequences of such a development for the pursuit of learning. Such consequences MacIntyre views as an ever increasing contentiousness and fragmentation, aggravated by the loss of common standards of appeal. Insofar as he sees a remedy for this malaise, it is in a restoration of an older order of rationality; an order with its own standards of authority, success and failure; an order which would articulate anew its long-standing merits and which would confidently proclaim these amid a prevailing coherence. 'We are waiting', he concludes, 'not for a Godot, but for another - doubtless very different - St. Benedict' (1981, p. 263).

Lyotard is not attracted by any prospect of a restoration of a premodern moral order, as he sees in this event the return of a hegemony associated with one or other 'metanarrative'. In an argument which embodies a disenchantment with emancipatory ideals and beliefs that has become a characteristic of postmodern sensibility, Lyotard insists that there is no question of pursuing a 'pure' alternative to the system. Such pursuits, he insists, would result in bringing about something akin to what they were meant to replace. Instead, Lyotard commends a continuing effort to destabilise all hegemonies, including that of 'the system' and its criterion of performativity. Rather than the goal of seeking consensus, which he claims 'does violence to the heterogeneity of language games' ( $p$. xxv), Lyotard advocates an active search for dissent ('paralogy'); for the invention of 'new moves' which disrupt all tendencies towards hegemony. This stance, he claims, 'refines our sensitivity to differences and reinforces our ability to tolerate the incommensurable' (p. xxv). In his more recent writings, this becomes refined as 'bearing witness to différends', where différend refers to that which resists all efforts to grasp and encapsulate it and then render it subject to the manipulative sweep of a logic of commensurability.

The critiques of the cultural predicaments of late modernity 
undertaken by MacIntyre and Loytard thus take contrary paths. Where fragmentation leading to ever greater disparity is lamented by MacIntyre, Lyotard sees in such a movement everything which is necessary to prevent the emergence of new repressive supremacies or uniformities.

The traditionalist lines of action favoured by MacIntyre are unlikely to find favour with policymakers in Western democracies, or in the newer power centres of the European Union, where a commitment to diversity and inclusion must not be seen to be abandoned. Neither are the modern centres of official power likely to embrace Loytard's analysis, with its criticisms of 'the ideology of the system', of the 'cynicism of its criterion of performance' (p. 65) and of 'decision makers who force on society the performance criterion they reject for themselves' (p. 64). Of course this is not to say that the analyses of Lyotard and MacIntyre are impotent. Such acute critique - whether premodern or postmodern in character - may cause more than a few shifts in prevailing currents of thought in educational and cultural circles, but it can hardly expect hospitality from those quarters where the critique hits hardest. The fact that their convictions and philosophical orientations are very different moreover should not obscure the point that there are some incisive parallels in the analyses of MacIntyre and Loytard: for instance, the demise of traditional ideals, the ubiquity of incommensurable outlooks, the hegemony of technocratic power, the preoccupation with effectiveness and performance rather than with substantive issues in official policy-making and its implementation.

Yet, when considered from an educational perspective, I would suggest that for all their perspicacity, neither critique reaches the core issue. This issue can be put in the form of a question as follows: How are the enduring concerns of teaching and learning as a public undertaking to be understood in the wake of modernity? And, more importantly, how are they to be constructively engaged? Can practices of teaching and learning be articulated and carried out in such a way that they do justice to inherited traditions, including their aspirations and disfigurements, while remaining worthy of the commitments of teachers, parents and students in circumstances of unprecedented diversity? In the absence of convincing answers to practical questions like these, albeit provisional or fallible answers, educational policy remains curiously vacuous at its heart and the conduct of education, while rushing to deliver the goods of performance, darts hither and thither around an enormous labyrinth. To the explorations of questions such as those which have now been opened up, attention must now be given. 


\section{The Diversity of Tradition and the Plurality of Talent}

What is actually accomplished by teaching is best understood not by consulting documented performance scores but by attending as closely as possible to the fullness of what befalls the understanding of learners in the practical contexts where teaching is attempted. Such close attention also repays better the purposes of assessment than does an almost exclusive reliance on an elaborate machinery of testing. That such machinery can be readily aligned to the requirements of indexed performance scarcely needs saying, but it is of little use if the inherent benefits of education are to play a significant part in what is called assessment. Indeed these benefits are frequently the first casualties, though unacknowledged as such, of the technicity of outlook which has increasingly become a reigning educational orthodoxy in Western countries. If they were acknowledged as casualties, or more particularly, to the extent that such an acknowledgement was made, then to that extent also there would be something of a forced political admission. This would be an admission possibly - à la Lyotard - that the substantive questions were no longer worth bothering about, or possibly - à la MacIntyre - that questions like 'Whose curriculum?' or 'Which tradition?' were now thrust forward with a new and discomfiting urgency. By side-stepping such an acknowledgement however, the modern politics of educational reform perpetuate an ambiguity which allows the performance criterion to win the day in practice while official lipservice can simultaneously be paid to the cultural importance of education.

Although a public acknowledgement of one or the other of those alternatives might be a salutary experience for policymakers to endure, it might still be of little practical benefit to the abiding concerns of teaching and learning; chiefly for the reason already alluded to, that neither the analysis of MacIntyre nor that of Lyotard reaches to the educational heart of the matter. Against the redoubtable case made by MacIntyre, it must be pointed out that, from an educational perspective, the central question is not that of: What tradition, or whose tradition, is to gain the upper hand in the curriculum by surpassing the claims of other contenders? It is not that a question of this kind is irrelevant, rather that it is a misconstrual. It becomes properly intelligible as an educational question only when its overt invitation to ideological combat is declined, in favour of a more inclusive engagement of what MacIntyre's question prematurely presents as a matter of either/or. The central question becomes, rather: How are we to respond, as human learners, to what 
addresses us from inheritances of learning - whether literary, mathematical, scientific, musical, technological, religious, or other? Reference here to inheritances of learning is not confined to accomplishments of previous generations. It also embraces contemporary developments in each and all fields of study, including recent and on-going researches. Similarly, the question 'How are we to respond as human learners?' is not restricted to some exclusive or cultured 'we'. Rather it includes within its scope not just pupils or students, though centrally these, but also teachers, parents, and critically policymakers - in fact all those differently disposed and differently circumstanced people who have, or who claim to have, a sincere and enduring concern with education as a human undertaking. In other words it is a question not to be dodged by those whose office is the demanding one of leadership or management any more than it is to be evaded by teachers in the daily difficulties of their work.

Bearing in mind these points, the central educational question can now be posed more precisely: How are we to respond to the diversity of what addresses us from inheritances of learning, even within a particular discipline or a particular tradition? Putting the question in this way highlights any possible rifts between policy and practice and allows us to concentrate more closely on the practical context mentioned at the start of this section. The question itself can be elaborated further as follows: Are there practices of teaching and learning which can succeed in making such inheritances speak to the abilities of very different kinds of learners - to their differing sensibilities and aptitudes - to their predispositions and their emergent identities? To venture 'yes' as the answer to these questions may seem foolhardy, or daunting. Be that as it may, it is just this venturing itself (and not an evasive preoccupation with indexing) which merits the centre stage in any thought and action that are properly to be described as educational. This 'yes' must be ventured moreover in a way that is both thoughtful and wholehearted, because an action of this kind helps to focus energies on what is distinctive and what is defensible in the occupational commitment of teaching. It also calls attention to the point that the virtues involved in this way of life are primarily communicative rather than combative ones; communicative both in the teacher's relation to traditions of learning and to other learners, including pupils and students, parents and, not least, teaching colleagues.

To clarify this point, recall that MacIntyre makes it a virtue to take an adversarial stance in articulating and defending one's own tradition in its encounters with others, while Lyotard makes a virtue of forms of learning and conduct which seek to destabilise any tradition 
which becomes an ascendancy. Traditional conceptions of teachers as 'defenders of the faith' are called to mind by the first kind of virtue, while the second one calls to mind a conception of teachers as militant opponents of any representation of them as functionaries of a 'system'. Both stances are familiar within the cultures of teaching. Still, although the spirited defence of a tradition, or determined opposition to domination, may sometimes feature prominently and appropriately in a teacher's work, neither defines the heart of teaching as a way of life. To become preoccupied with either moreover may obscure a proper understanding of what is most central to that way of life. What is central is the twofold communicative relation referred to briefly a moment ago and worth stating in more detail now: first, the quality of the teacher's relation to those parts of an inheritance of learning (e.g. history, physics, music) which live actively and questioningly in the teacher's own experience as a learner; second, the quality of the teacher's enactments of that living inheritance, including the handling of its inherent tensions and intractabilities, in the daily and diverse circumstances of teaching and learning itself.

The kinds of relations involved here, and the communicative virtues which are properly embodied in them, are something quite other than a 'transmission of skills', an 'imparting of knowledge', or 'the passing on of a cultural heritage'. Each of these everyday phrases involves too static an understanding, too institutionalised a conception, of what I have called a living inheritance. The one-way character of these descriptions, moreover, though less unbecoming than the ubiquitous misnomer 'delivery of the curriculum', embodies an outlook which is still of a part with it. Phrases like these betray a mistaken conception of tradition as something monolithic, an attenuated view of learning as an acquiescence in received certainties, and a misunderstanding of teaching as that which efficiently brings about such acquiescence.

In contrast to all conceptions of this kind, teaching and learning are properly to be understood as a jointly attempted undertaking by teachers and pupils. This is an undertaking which may variously be frustrated or facilitated, aborted or advanced, subverted or sustained, by those who are participants in it, or by others who are not. But it is also an undertaking which is essentially a renewable, an unfinished and an unfinishable one, even where only a single subject of study, or inheritance of learning is concerned. So of first importance in the teacher's relation to what is being taught is the virtue born of a genuine fluency; namely, an educated sense of one's own ignorance. This contrasts notably with qualities tending towards 
conceit or presumptuousness, dogmatism or infallibility, which are more than occasionally attributed to teachers.

An educated sense of one's own ignorance means, for the thoughtful teacher, that the accomplishing of higher standards of fluency and proficiency in any field of study reveals a vista of more unanswered than answered questions; a neighbourhood of ever additional voices, where, in Oakeshott's memorable prose, 'thoughts of different species take wing and play around one another, responding to each other's movements and provoking one another to fresh exertions' (Oakeshott, 1962, p. 198). It is important to stress in this connection that the teacher's relations with his or her pupils also constitutes a crucial field of study, no less so indeed than do the inheritances of learning themselves. When properly undertaken, the study of communicative experience discloses insights and possibilities which may give one reason to listen with fresh ears and to revise what one already knows perhaps too well. This also implies that one becomes keen to learn from one's previous mistakes as learner or as teacher, including those where one ventured confidently unaware of biases that lay smothered beneath the most apparently successful of classroom performances.

The discipline involved in the teacher's relations with a living inheritance of learning - in science, or history, or religion, or whatever - becomes important in the most public and delicate way then wherever the enactments of teaching are attempted. Most teaching is at once the most personal and the most public of human experiences. What remains hidden from the eyes of colleagues by the four walls of one's classroom remains vulnerable to the probing attentions and sensitive antennae of a diverse audience of pupils. The significance of what is thus spontaneously exposed is often overlooked by teachers themselves, perhaps understandably so, in the urgency of covering the topic of the lesson in question, frequently with a view to assessments that loom ahead.

The diversity among pupils - of sensibility, of disposition, of ability - increases apace. On accounts like those of MacIntyre and Lyotard, it may often more accurately be called a disparity. Even within a single classroom, such a diversity or disparity of sensibility is likely to attribute to the teacher, mistakenly or otherwise, a greater range of shortcomings than might the evaluations of a critical colleague. The teacher is likely moreover to remain unaware of the more salient judgements thus pronounced, as the 'tribunal' is likely to convene in the informal setting of the school playground, or to reconvene without notice in any number of the pupils' homes. Its verdicts moreover are unlikely to issue in anything like a coherent 
communication to the teacher. And such verdicts, once voiced by juries of adolescent or indeed younger peer groups, are not easily set aside or reversed. They constitute a powerful collateral kind of learning which may place inscrutable, intractable, or misdiagnosed obstacles in the paths of a teacher's best efforts to get fruitful learning underway. They may continually bring such efforts promptly to grief.

This hidden curriculum which we have been unveiling in the previous paragraphs always embodies inherent vices, or virtues, or both. It affects in a decisive way the quality of the encounters between pupils and the inheritances of learning into which teaching seeks to introduce them and in which it seeks to sustain them as increasingly fluent and active participants. Its inconspicuous influences co-ordinate the diverse responses of pupils into certain patterns. It thus shapes the abiding attitudes and beliefs which take root among pupils in the course of their schooling, including their attitudes to teachers, to different fields of study, even to the very idea of study itself and to the place of learning in their lives. The greater the obstacles it creates the greater the likelihood of its opacity to the teachers and of its intractability to remedial efforts. By contrast, if it somehow establishes a prejudice among learners in favour of the teacher and his or her efforts, it works as a virtuous rather than as a vicious circle. One way or the other, it constitutes a collateral learning which, as Dewey (1938) pointed out, may be more important in the long run that the contents of the lesson being taught.

Yet, like many more overt aspects of the practices of teaching, this active but unannounced curriculum remains unaddressed by the international educational reforms of recent decades, including those which have sought to make central the issue of 'quality in teaching'. (See, for instance, the reports Teaching Quality UK [HMSO, 1983]; Schools and Quality - An International Report [OECD, 1989]; Teaching and Learning: towards the learning society [European Commission White Paper on Education and Training, 1996].) This continual omission recalls the vacancy in official educational thinking referred to earlier: the apparent absence of a capacity, or perhaps of a will, to get incisively to the heart of the matter, and the substitution instead of reform measures which are populist and plausible, but which are more importantly an evasion of the real challenges of education. More critically viewed then, the major omissions at the heart of the more significant educational reforms of recent decades constitute in effect a cultural disinheriting of the young, unwitting or otherwise, which is officially decreed and enforced. 
Some indications have already been given above that education has its own inherent virtues and that these lie elsewhere than where politically motivated reform efforts have been disposed to look. It is time to acknowledge and affirm them more directly now by illustrating their embodiment in educational practices. The practices in question are among the more enriching and defensible, but also among the more daunting, of human undertakings. This illustration and affirmation will be the main task of the concluding section.

\section{Disclosing the Virtues of Education in Practice ${ }^{3}$}

Let us consider, by exploring a few examples, how virtues and vices are embodied in the actions of the participants as teaching and learning are attempted. If I teach history, or English, or science, or religion, or any other subject in a school curriculum, it is right and fitting that I should encourage my pupils to see that I believe that the subject I am teaching has something rich and enduring to offer. This captures an initial sense of what it means for the subject to be a living inheritance. It is equally fitting moreover that I should wish my pupils to share something of my own enthusiasm for that inheritance: that my occupational commitment as a teacher should express itself - taking the four examples mentioned - in encouraging them individually and collectively to discover something of the historian in themselves, or something of linguistic aptitude and literary appreciation in themselves, or something of the scientist in themselves, or something of their own spiritual sensibilities. Yet this is not to deny that it may take inspired pains, discerning faith and sterling reserves of equity and forbearance on the teacher's part to unearth that 'something'. Neither is it to deny that the 'something' may initially look quite insignificant even when it is unearthed. Such unearthing, however, invariably marks an event of emancipation, or release, of the pupils from a previously constraining state. It enables the pupils to understand something more of her own capacities for learning, her own particular potentials, her own aptitudes and limitations; to take a genuine step in the gradual appropriation of her own identity.

The picture is quite different, however, and gives justified grounds for disquiet if, as a history teacher, I seek to inculcate in the pupils a personal allegiance of my own to an officially sanctioned, or otherwise tendentious version of the past; if, as a science teacher, I seek to silence any side of the argument on safe sources of energy; if, as a teacher of English, I insinuate the view that this language confers the badge of cultural or racial superiority; if, as a teacher of 
religion, I treat matters of faith as if they were matters of fact; if, in any instance of teaching, my approach presumes some proprietorial claim on the sensibilities of the pupils. Unless the disavowal of such a claim becomes an imperative of professional discipline in teaching, the interplay of influence between teachers and pupils may become rapidly, even irrevocably, disfigured.

The point to emphasise here is that, far from being a morally neutral undertaking, certain virtues and vices are already active where teaching is attempted. Pressing this further, and despite any displeasure of pre-modernists or any 'incredulity' of postmodernists at the point, there are virtues of teaching which can claim to be universal, as distinct from sectional or factional in character: virtues, that is, which are educational before they are anything else. As fallible but deserving candidates for the convictions of teachers, such virtues can now be seen to include: a circumspect honesty in declaring one's own intentions as a teacher; the courage, moral energy and perseverance to tackle challenges and obstacles; patience and persistence which are adroit rather than importunate; frankness, coupled with respect for each pupil's privacy and dignity; an originality which resists the ruts of habit and returns ever anew to the inheritances of learning which are the teacher's abiding point of contact with the pupils; a judicious faith in pupils, even in unpromising circumstances, informed by an attentive and sympathetic understanding; a disavowal of proprietorial designs on pupils' minds and hearts, coupled with an educated sense of one's own ignorance and a constructive sense of self-criticism; a wholehearted care for pupils as young learners, recognising the claims of both equity and difference, and with unfailing expectations ever in attendance; a willingness to co-operate actively with colleagues in pooling ideas, testing different approaches, building on good practice; a commitment to include pupils, insofar as possible, as responsible participants in learning and to regard parents as an informed support in this effort. If the list here appears long, it is still a representative rather than an exhaustive one. It proceeds from an understanding that is constitutive of education as a coherent practice in its own right, as distinct from other practices which have understandings and virtues proper to themselves - for instance, medicine, politics, law, business, religious ministry.

It must be emphasised then that these virtues of teaching are human practices, rather than merely attitudes. They are still not the same however as the skills of teaching (e.g. classroom management skills) though they can dramatically transform how the skills of teaching are exercised. The virtues of teaching are concerned, first 
and foremost, with releasing and enabling pupils. This does not mean any kind of release or enablement; rather it means uncovering the tenor and scope of each pupil's own most promise and potentials, nurturing these attentively and disciplining their exercise to take account of the rights, viewpoints and feelings of others. The specific, yet universal character of these virtues of teaching is what makes them candidates worthy of the occupational commitments of teachers as professionals, as distinct from teachers as persons of a particular religion, or political persuasion, or ethnic allegiance. Such virtues are thus to be distinguished from teachers' personal convictions in matters of ethics, politics, religion, etc., although they may well be in harmony with, or draw sustenance from, the latter.

The virtues of teaching just mentioned promote a commitment not to doing battle on behalf of one tradition against others, but to the actual bringing about in some sustained measure (not just the facilitation) of a genuine engagement between the emergent potentials of the pupils and the authentic voices of the differing subjects which seek to address these potentials. In the case of all subjects, the attempt to call forth a substantial response from the pupils is, at the same time, an attempt to call forth some accompanying qualities, namely virtues of learning. As a corollary of what has been argued already, the virtues of learning can be seen to include: a commitment to effort in the pursuit of fluency; tolerance and co-operation among learners in relation to teach other's attempts and ventured contributions; method and growing discernment in their efforts to understand; acknowledgement of the claims of balance in the exercise of critical judgement; acknowledgement to the requirements of equity in all aspects of learning; receptive openness by learners to what is decently addressed to them; readiness to ask questions and to raise critical queries; willingness to take responsibility for one's own learning.

It might be tempting to object here that these virtues of teaching and learning are nothing short of a list of the requirements for sainthood. This kind of objection however bypasses everything that is distinctive, if also difficult, in teaching. The practice of these virtues is not an all or nothing affair of success or failure. Rather, as in most human practices dedicated to the pursuit of inherent goods, success and accomplishment are a matter of degree, of renewed attempts often following frustrated efforts. In this case however, the goal itself is more a pathway than a destination. More precisely, it is experienced at its best as an ironically edifying journey to a horizon which grows richer even as it remains beyond reach. It is thus to be distinguished from any final grasp of the truth or any final arrival in 
victory or supremacy. An appreciation of this recalls the singular and continuing significance for teaching and learning of Socrates of Athens (as distinct from the Socrates of Plato's later writings), whose educational work still provides some unsurpassed examples of the virtues in question. It may be unrealistic to expect politicians to practise such virtues in any widespread way. It is a reasonable expectation in a democracy, however, that they should not merely tolerate, but actively encourage their exercise in places of learning. More particularly, educational policy - including reform efforts - might then be viewed as the promotion of that human undertaking where the exercise of such virtues is especially appropriate; an undertaking which is at its heart defined by such exercise.

\section{NOTES}

1. The experience of reform in the author's own country, Ireland, is largely different to the pattern just described. Although educational reform in the Republic of Ireland is not without its difficulties and frustrations, recent Irish governments have committed themselves to a partnership model of formulation and implementation of all social, economic and educational policy. Where the latter is concerned, this new development had its origins in the National Education Convention of 1993, was further articulated in a 1995 White Paper, Charting our Education Future, and was enshrined in the Education Act of 1998.

2. The 1996 White Paper of the European Commission, Teaching and Learning: towards the learning society, provides some good examples of this strategic use of ambiguity. The Paper seeks to dissolve the distinction between education and training and clearly regards education chiefly as an instrument of EU economic and social policy. Its references to the personal and cultural purposes of education are few and passing ones, like the following: 'The essential aim of education and training has always been personal development and the successful integration of Europeans into society through the sharing of common values, the passing on of cultural heritage and the teaching of self reliance' (p. 18). Even a preliminary elaboration of the reference to cultural heritage here would point to an immense diversity in European heritages of learning - a diversity whose oppositions and conflicts would need to be experienced and seriously studied before any conclusion about the 'sharing of common values' could be drawn. No such elaboration is evident anywhere in the White Paper, although detailed consideration is given to 
economic and social issues and to furthering an individualist and competitive outlook through educational institutions.

3 . The arguments in this section are a revised and edited version of those first put forward in Hogan (1995), Ch. 6.

\section{REFERENCES}

Coolahan, J. (1977) The ideological framework of the payment by results policy in nineteenth century education, Proceedings of the Educational Studies Association of Ireland, 166-171.

DewEY, J. (1938, 1963) Experience and Education (New York, Macmillan).

EuRopeAn Commission (1996) Teaching and Learning: towards the learning society, A White Paper on Education and Training (Brussels, Directorate General 22 of the Commission of the European Communities).

Haydon, G. (1987) Education and Values - The Richard Peters Lectures (London, University of London Institute of Education).

Hogan, P. (1995) The Custody and Courtship of Experience - Western Education in Philosophical Perspective (Dublin, Columba Press).

HMSO (1983) Teaching Quality, Paper presented to Parliament by the Secretary of State for Education and the Secretary of State for Wales (London, Her Majesty's Stationery Office).

Lyotard, J. F. (1979, 1984) The Postmodern Condition, translated by G. Bennington and B. Masumi, with Foreword by F. Jameson (Manchester, Manchester University Press).

Lyotard, J. F. (1988) The Différend: Phrases in Dispute, translated by G. Van Den Abbeele (Manchester, University of Manchester Press).

MacinTyRe, A. (1981, 1985) After Virtue - a Study in Moral Theory (London, Duckworth).

MaCinTYRE, A. (1988) Whose Justice? Which Morality? (London, Duckworth).

Macintyre, A. (1990) Three Rivals Versions of Moral Enquiry (London, Duckworth).

Maritain, J. (1943, 1960) Education at the Crossroads (New Haven, Yale University Press).

Marrou, H. (1956) A History of Education in Antiquity, translated by G. Lamb (New York, Sheed and Ward, 1956).

OAKESHOTT, M. (1962) The voice of poetry in the conversation of mankind. In Rationalism in Politics and Other Essays (London, Methuen).

OECD (1989) Schools and Quality - An International Report (Paris, Organisation for Economic Co-operation and Development).

Correspondence

Dr Pádraig Hogan

Department of Education

National University of Ireland - Maynooth

Maynooth

Co. Kildare

Ireland 